Aisyah Journal of Informatics and Electrical Engineering Universitas Aisyah Pringsewu

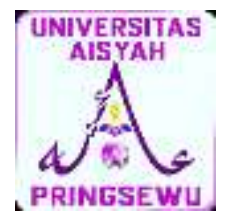

Journal Homepage

http://jti.aisyahuniversity.ac.id/index.php/AJIEE

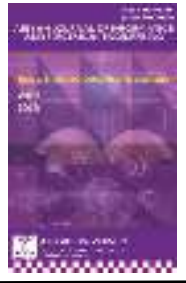

\title{
Sistem Pendukung Keputusan Promosi Kenaikan Pangkat Jabatan Fungsional Pegawai Terbaik Berdasarkan Nilai Angka Kredit Menggunakan Metode Weighted Product dan Promethee
}

\author{
FahlulRizki $^{1}$, Zulkifli $^{2}$, Nurul Isti Fada $^{3}$ \\ 1,2,3 Program Studi Teknik Informatika \\ 1,2,3 Universitas Aisyah Pringsewu \\ e-mail:Fahlulrizki120@gmail.com ${ }^{1}$,Zulkiflist13@gmail.com²
}

\begin{abstract}
Abstrak
Pengukuran kinerja karyawan pada pemerintahan sangat penting guna evaluasi dan perencanaan masa depan. Penilaian prestasi kerja penting bagi badan pemerintahan untuk menetapkan tindakan kebijaksanaan selanjutnya. Penilai cenderung beranggapan bahwa dia harus bersikap baik terhadap karyawannya, jadi nilai yang diberikan baik terhadap semua aspek penilaian bias. Penilai seringkali dipengaruhi oleh faktor: umur, ras, dan jenis kelamin sehingga sangat mempengaruhi peringkat karyawan.
\end{abstract}

Algoritma promethee memiliki tingkat akurasi tertinggi yaitu $86.37 \%$ sedangkan weighted product sebesar $80.89 \%$ maka selisih diantaranya sebesar $6 \%$. Model algoritma Prometheedapat melakukan perangkingan secara acak tanpa melihat kelompok golongan, yang artinya jika ada 100 data maka metode promethe akan melakukan system perhitunga rangking sesuai dengan angka kredit tertinggi tanpa melihat terlebih dahulu kelompok golongan yang ada. Rule yg dihasilkan algoritma prometheemelalui bererapa tahap lebih banyak daripada rule weighted product. Berdasarkan akurasi yg dihasilkan prototype menunjukkan bahwa metode dan prototype yg diterapkan sudah baik dalam memprediksi keputusan kenaikan jabatan fungsional berdasarkan angka kredit.

Kata Kunci: SPK promosi jabatan fungsional karyawan terbaiki. 


\section{Pendahuluan}

Didalam sebuah perusahaan atau organisasi, karyawan merupakan asset terpenting yang dimiliki oleh perusahaan dalam usahanya mempertahankan kelangsungan hidup, berkembang, berkemampuan untuk bersaing dan memperbaiki taraf hidupnya. Dalam organisasi pemerintahan peningkatan mutu karyawan dapat meningkatkan pelayanan yang baik terhadap masyarakat. Pengukuran kinerja karyawan pada pemerintahan sangat penting guna evaluasi dan perencanaan masa depan. Penilaian prestasi kerja penting bagi badan pemerintahan untuk menetapkan tindakan kebijaksanaan selanjutnya. Penilai cenderung beranggapan bahwa dia harus bersikap baik terhadap karyawannya, jadi nilai yang diberikan baik terhadap semua aspek penilaian bias. Setiap organisasi atau perusahaan memerlukan sumber daya untuk mencapai tujuannya. Sumber daya merupakan sumber energi, tenaga, kekuatan yang diperlukan untuk menciptakan daya, gerakan, aktivitas, kegiatan, dan tindakan (Amiri, MP 2010). Sumber daya tersebut antara lain terdiri atas sumber daya alam, sumber daya finansial, sumber daya manusia, sumber daya ilmu pengetahuan, dan sumber daya teknologi.

\subsection{Masalah Penelitian}

Kompleksitas permasalahan yang ada dalam organisasi pemerintahan dengan sendirinya menuntut adanya suatu manajemen yang baik khususnya terhadap sumber daya manusia. Masalah yang terjadi pada Pemerintahan Polisi Pamong Praja Pringsewu adalah kurangnya kemampuan dalam mengoprasikan komputer, penilaian karyawan hanya dengan menggunakan Microsoft Excel dengan begitu penilaian tidak objektif, terkadang pimpinan merasa keliru dalam menilai karyawan yang akan naik jabatan.

\subsection{Identifikasi Masalah}

Berdasarkan permasalahan yang sudah pernulis uraikan maka masalah dapat diidentifikasikan sebagai berikut:

1. Terdapat beberapa kendala dalam pengelolaan SDM.

2. Sering muncul subjektifitas dari para pengambil keputusan dalam menentukan kriteria promosi jabatan karyawan.

3. Banyaknya penempatan sumber daya manusia pada jabatan-jabatan yang tidak sesuai dengan keahliannya.

4. Seorang pimpinan hanya memandang pada sumber daya 
manusia yang sudah dianggap senior atau pendidikannnya tinggi.

5. Kurangnya kemampuan sistem yang ada dalam melakukan penilaian karyawan terbaik hanya dari memanfaatkan program Microsoft Excel.

6. Terbatas untuk beberapa kriteria utama seperti Pendidikan, pangkat dan nilai kerja.

\subsection{Batasan Masalah}

Agar penelitian tidak meluas atau terfokus pada tujuan maka dibuat beberapa batasan masalah, yaitu sebagai berikut:

1. Sistem Pendukung Keputusan ini dibuat dalam ruang lingkup menyeleksi karyawan yang berhak untuk promosi jabatan yang bertujuan untuk memberikan nilai dan perangkingan sehingga dapat menjadi rekomendasi/pertimbangan bagi pimpinan yang akan memilih karyawan tersebut untuk mendapatkan promosi jabatan.

2. Sistem dikembangkan dengan dua metode yaitu WP dan Promethee berbasis website menggunakan bahasa pemrograman PHP dan MySql sebagai databasenya

3. Penelitian ini bersifat statis, kriteria yang digunakan dalam pemilihan karyawan terbaik terdiri dari nilai kerja, pangkat,

Pendidikan, kehadiran, produktifitas(hasil kerja), integritas(sifat), skill(kemampuan dan loyalitas (kesetiaan), dan kriteria dapat diubah sesuai dengan kebutuhan

\subsection{Rumusan Masalah}

Rumusan masalah merupakan inti masalah yang dinyatakan sebagaimana yang telah disampaikan dalam identifikasi masalah. Adapun rumusan masalah ini adalah sebagai berikut:

1. Bagaimana merancang dan membangun sistem pendukung keputusan pemilihan karyawan terbaik dengan menggunakan dua metode yaitu: WP dan Promethee untuk membantu pimpinan pembuat keputusan mengambil keputusan terbaik?

2. Bagaimana sistem pendukung keputusan promosi jabatan dengan kombinasi dua metode WP dan Promethee dapat membantu pengambil keputusan dalam promosi jabatan dengan cepat, lebih akurat, adil, objektif, dan dapat mengatasi masalah pemilihan karyawan yang berhak untuk promosi jabatan? 
3. Bagaimana memilih metode terbaik yang bisa digunakan untuk melakukan pemilihan karyawan terbaik untuk kenaikan pangkat sebagai penghasil keputusan paling akurat?

\subsection{Tujuan dan Manfaat Penelitian}

\section{Tujuan}

Sesuai dengan perumusan masalah di atas maka penelitian ini dilakukan dengan tujuan untuk menganalisis dan membuktikan secara empiris yaitu:

1. Merancang Sistem Penunjang Keputusan yang berguna untuk menyeleksi karyawan untuk promosi jabatan karyawan terbaik.

2. Penerapan metode WP dan Promethee untuk memperoleh solusi terbaik sistem pendukung keputusan yang adaptif, interaktif, fleksibel yang mendukung solusi dari permaslahan manajemen dalam meningkatkan kualitas pengambilan keputusan sesuai harapan.

3. Merancang sistem pendukung keputusan untuk menghasilkan sistem informasi yang sesuai dengan standar kualitas perangkat lunak ISO 9126 menurut aspek functionality, reliability ,usability, efficiency, dan performance.

\section{Manfaat}

Penelitian ini diharapkan nantinya memberikan manfaat antara lain:

1. Manfaat Akademis

a. Penelitian ini selain sebagai salah satu syarat dalam memperoleh gelar Magister dan menerapkan ilmu yang telah diperoleh dengan cara melakukan penelitian tentang metode Weighted Product dan promethee.

b. Penelitian ini juga diharapkan dapat memberikan kontribusi terhadap konsep sistem pendukung keputusan menggunakan metode Weighted Product dan Promethee khususnya. Hasil dari penelitian ini diharapkan dapat mengembangkan pengetahuan, menambah wawasan kepustakaan pendidikan serta dapat menjadi referensi bagi penelitian selanjutnya.

2. Manfaat Praktis

Hasil dari penelitian ini diharapkan dapat menjadi alternatif solusi dari masalah promosi jabatan dan menjadi solusi untuk referensi promosi jabatan pemilihan karyawan terbaik di lingkungan Pemerintahan Polisi Pamong Praja Pringsewu. 


\section{TINJAUAN PUSTAKA}

\subsection{Sistem Pendukung Keputusan}

Sistem Pendukung Keputusan merupakan sistem informasi interaktif yang menyediakan informasi, permodelan dan pemanipulasian data. Sistem itu digunakan untuk membantu pengambilan keputusan dalam situasi yang semi terstruktur dan situasi yang tidak terstruktur, dimana tidak seorangpun tahu secara pasti bagaimana keputusan dibuat.

Sistem Penunjang Keputusan bertujuan untuk menyediakan informasi, membimbing, memberikan prediksi serta mengarahkan kepada pengguna informasi agar dapat melakukan pengambilan keputusan dengan lebih baik. Sistem Pendukung Keputusan merupakan implementasi teori - teori pengambilan keputusan yang telah diperkenalkan oleh ilmu-ilmu seperti Operation Research and Management Science, hanya bedanya adalah bahwa jika dahulu untuk mencari penyelesaian masalah yang dihadapi harus dilakukan perhitungan iterasi secara manual (biasanya untuk mencari nilai minimum dan maksimum), saat ini komputer PC telah menawarkan kemampuannya untuk menyelesaikan persoalan yang sama dalam waktu yang relatif singkat.

\section{2 karakteristik kemampuan SPK}

Menurut

Turban(2005)

menjelaskan terdapat sejumlah karakteristik dan kemampuan SPK yaitu:

1. SPK merupakan sistem berbasis komputer dengan antarmuka antara mesin/komputer dengan pembuat keputusan.

2. Memberikan hak penuh kepada pembuat keputusan untuk mengontrol seluruh tahap dalam proses pembuatan keputusan.

3. SPK mampu memberi solusi bagi masalah tidak terstruktur, baik bagi perorangan atau kelompok.

4. SPK mengunakan data, basis data, dan analitis metode-metode keputusan.

5. Kemampuan SPK adalah dapat melakukan adaptasi setiap saat dan bersifat fleksibel.

6. SPK ditujukan untuk membantu pembuat keputusan dalam menyelasaikan masalah dan bukan menggantiposisimanusia sebagai pembuat keputusan.

\section{3 tahap-tahap SPK}

Menurut Herbert A. Simon (Asfi, 2010: 2) proses pengambilan keputusan mempunyai 3 tahap,yaitu:

1. PemahamanMenyelidiki

lingkungan kondisi-kondisi yang memerlukan keputusan data mentah 
yang diperoleh, diolah dan diperiksa untuk dijadikan petunjuk yang dapat menentukan masalahnya.

2. Perancangan Menemukan, mengembangkan, dan menganalisis arah tindakan yang mungkin dapat dipergunakan. Hal ini mengandung proses-proses untuk memahami masalah, untuk menghasilkan cara pemecahan, dan untuk menguji apakah cara pemecahan tersebut dapat dilaksanakan.

3. Pemilihan Memilih arah tindakan tertentu dari semua arah tindakan yang ada. Pilihan ditentukan dan dilaksanakan.

\subsubsection{Metode Weighted Product (WP)}

Metode Weighted Product adalah salah satu metode dalam sistem pengambilan keputusan, dimana pengambilan keputusan dapat dilakukan secara lebih cepat, tepat dan sesuai dengan kriteria yang diinginkan atau setidaknya hampir mendekati kriteria yang diinginkan. Metode ini menggunakan perkalian untuk menghubungkan nilai kriteria, dimana nilai setiap kriteria harus dipangkatkan dulu dengan bobot kriteria yang bersangkutan. Proses ini samahalnya dengan proses normalisasi.

\section{METODOLOGI}

\subsection{Metode Penelitian}

Metode penelitian yang digunakan adalah metode analisis deskriptif dengan pendekatan kuantitatif artinya penelitian yang dilakukan adalah menekankan analisanya pada data-data numeric (angka), yang bertujuan untuk mendapatkan gambaran yang jelas mengenai suatu keadaan berdasarkan data yang diperoleh dengan cara menyajikan, mengumpulkan dan menganalisis data tersebut sehingga menjadi informasi baru yang dapat digunakan untuk menganalisa mengenai masalah yang sedang diteliti

\subsection{Metode Pemilihan Sampel}

Sampel adalah suatu proses menyeleksi porsi dari populasi untuk dapat mewakili populasi (Sugiyono 2003). Sampel yang digunakan dari data PNS Satuan Polisi Pamong Praja Kab. Lampung Utara yang diambil dari tahun 2019 - 2020. Metode penarikan sampel yang dilakukan dalam penelitian ini adalah purposive (disengaja). Populasi adalah wilayah generalisasi yang terdiri atas objek/subjek yang mempunyai kuantitas dan karakteristik tertentu yang ditetapkan oleh peneliti untuk 
dipelajari dan kemudian ditarik kesimpulannya (Sugiyono 2003).

\subsection{Metode Pengumpulan Data}

Dalam penilitian ini, peniliti melakukan pengumpulan data dengan cara mengambil data secara langsung yaitu di wilayahSatuan Polisi Pamong Praja Kab. Lampung Utara, adapun data yang digunakan adalah data primer dan sekunder tanpa perantara pihak lain.

\subsubsection{Analisis sistem berjalan}

Menurut hasil wawancara yang dilakukan dengan bagian kepegawaian Satuan Polisi Pamong Praja Kab. Lampung Utara sistem untuk melakukan penilaian kinerja pegawai masih menggunakan cara yang manual. Bagian kepegawaian mendapatkan data yang dikumpulkan dari kepala bagian setelah itu baru dilakukan penilaian yang masih bersifat subjektif dimana penilai masih menggunakan parameter yang global.

\subsubsection{Analisis kebutuhan}

Dalam pelaksanaan promosi jabatan syarat-syarat sebagai dasar pelaksanaan promosi jabatan perlu diperhatikan dan dilakukan baik dilihat dari segi kepentingan organisasi maupun pegawai. Dengan adanya syarat-syarat promosi jabatan yang telah ditetapkan sebelum dilaksanakan, maka akan memudahkan bagi pimpinan untuk merencanakan dan melaksanakan promosi jabatan, dilain pihak pegawai akan berusaha untuk memenuhi syaratsyarat tersebut agar dapat dipromosikan. Penilaian prestasi kerja juga dapat digunakan oleh instansi untuk mengetahui kekurangan dan potensi seorang pegawai.

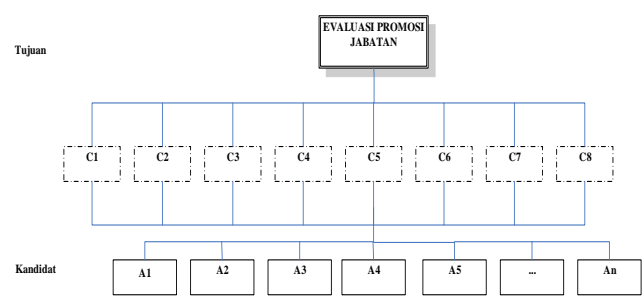

Gambar Kriteria Penilaian

Tabel Kriteria Umum

\begin{tabular}{|c|c|c|c|}
\hline $\mathrm{N}_{0}$ & Kriteria Imum & Rinian & Simbol \\
\hline 1 & Pendidikan & Pendidikan sekolhd dan jazahlgelar & C1 \\
\hline \multirow{2}{*}{2} & \multirow{2}{*}{ Lamanya Menghutidikikat } & Dikat fungsionalteknis & \multirow{2}{*}{ Q 2} \\
\hline & & Dikat Prajabotan & \\
\hline \multirow{3}{*}{3} & \multirow{3}{*}{ Peneggkan Perda } & 1.Pęaksonaan penindakan y ystisi & \multirow{3}{*}{ C3 } \\
\hline & & 2.Peaksonaan penindakan non yustisi & \\
\hline & & 3Evaluasip penegegkan Perda dan Peraturan Kepala Daerah & \\
\hline \multirow{6}{*}{4} & \multirow{6}{*}{ 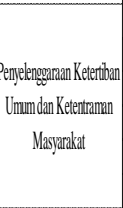 } & 1.Penbutatan nencana induk (master plan) & \multirow{6}{*}{ C4 } \\
\hline & & 2Pelksanaan patoli: & \\
\hline & & 3.Pengamanandan pengawahn; & \\
\hline & & 4.Penendalannmassi; & \\
\hline & & 5.Pendektesinandini; dan & \\
\hline & & 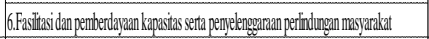 & \\
\hline \multirow{3}{*}{5} & \multirow{3}{*}{ Penembangangan Protesi } & 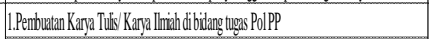 & \multirow{3}{*}{$c 5$} \\
\hline & & 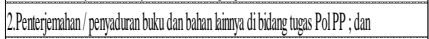 & \\
\hline & & 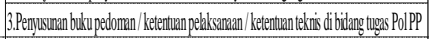 & \\
\hline \multirow{6}{*}{6} & \multirow{6}{*}{ Unsur Pennimang } & 1.Pengagar pelath pada dikat fingsional/teknis dibidang tugas PolPP & \multirow{6}{*}{ C6 } \\
\hline & & 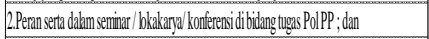 & \\
\hline & & 3.Keangevotand dalam Organiassi Protessi & \\
\hline & & 4...Keangovotand dahm Tim Perlahí & \\
\hline & & 5.Perolhan Penghargean/Tanda Jasa & \\
\hline & & 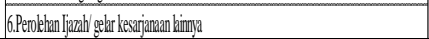 & \\
\hline
\end{tabular}

\section{HASIL DAN PEMBAHASAN}

\subsection{Pengukuran Penelitian}

\subsubsection{Pengelompokan dan Analisis}

Data

Sistem penunjang keputusan sebagai kenaikan pangkat jabatan fungsional Pol 
PP berdasarkan Angka Kredit dimulai dari pengolahan data pegawai PNS Satuan Polisi Pamong Praja Kabupaten Lampung Utara, dilanjutkan penilaian kriteria untuk promosi jabatan pegawai dengan memasukkan nilai keanggotaan dari setiap kriteria. Pembobotan kriteria untuk promosi jabatan pegawai menggunakan metodeWeighted Product dan Promethee.

\subsubsection{Penentuan kriteria}

Dalam perhitungan bobot kriteria langkah pertama adalah menghitung tingkat kepentingan perbandingan berpasangan dari masing-

\begin{tabular}{|c|c|c|c|c|c|c|c|}
\hline A4 & $\begin{array}{c}\text { Pembin } \\
\text { a, IV/a }\end{array}$ & $\begin{array}{c}10 \\
0\end{array}$ & 10 & 4 & 5 & 5 & 15 \\
\hline A5 & $\begin{array}{c}\text { Pembin } \\
\text { a, IV/a }\end{array}$ & $\begin{array}{c}15 \\
0 \\
\end{array}$ & 10 & 4 & 5 & 3 & 12 \\
\hline A6 & $\begin{array}{l}\text { Pembin } \\
\text { a, IV/a }\end{array}$ & $\begin{array}{c}10 \\
0\end{array}$ & 10 & 5 & 4 & 3 & 12 \\
\hline A7 & $\begin{array}{l}\text { Penata } \\
\text { TK.I, } \\
\text { III/d }\end{array}$ & $\begin{array}{c}10 \\
0\end{array}$ & 8 & 3 & 3 & 2 & 10 \\
\hline A8 & $\begin{array}{l}\text { Penata } \\
\text { TK.I, } \\
\text { III/d }\end{array}$ & $\begin{array}{c}10 \\
0\end{array}$ & 8 & 3 & 4 & 4 & 15 \\
\hline A9 & $\begin{array}{l}\text { Penata } \\
\text { TK.I, } \\
\text { III/d }\end{array}$ & 60 & 8 & 2 & 4 & 4 & 10 \\
\hline A10 & $\begin{array}{l}\text { Penata } \\
\text { TK.I, } \\
\text { III/d }\end{array}$ & $\begin{array}{c}10 \\
0\end{array}$ & 10 & 2 & 2 & 3 & 8 \\
\hline
\end{tabular}
masing kriteria yaitu: Pendidikan (C1), Lamanya Mengikuti $\operatorname{Diklat}(\mathrm{C} 2)$, 4.2.2 Penentuan nilai vector PenegakanPERDA(C3),Penyelenggaraa n Ketertiban Umum dan Ketentraman Masyarakat (C4), Pengembangan Profesi (C5), Unsur Penunjang (C6). Dengan menggunakan rumus persamaan pada metode wighted product didapatkan nilai vector seperti terlihat pada table 4.4

Berikut adalah tabel jenis dan kriteria penilaian.

\subsubsection{Evaluasi kandidat pegawai}

Data kandidat yang dipilih untuk mengikuti pemilihan promosi jabatan dapat ditunjukkan pada tabel berikut. Terdapat 10 sample yang diujicobakan pada evaulasi kandidat yang terpilih seperti pada tabel 4.3

\begin{tabular}{|c|c|c|c|c|c|c|c|}
\hline $\begin{array}{c}\text { KOD } \\
\text { E }\end{array}$ & $\begin{array}{c}\text { Golonga } \\
\mathrm{n}\end{array}$ & $\mathrm{C} 1$ & 2 & 3 & 4 & 5 & 6 \\
\hline \multirow{2}{*}{ A1 } & $\begin{array}{c}\text { Pembin } \\
\text { a, IV/a }\end{array}$ & $\begin{array}{c}10 \\
0\end{array}$ & 15 & 6 & 6 & 6 & 15 \\
\hline \multirow{2}{*}{ A2 } & $\begin{array}{c}\text { Pembin } \\
\text { a, IV/a }\end{array}$ & $\begin{array}{c}10 \\
0\end{array}$ & 12 & 6 & 6 & 4 & 10 \\
\hline \multirow{2}{*}{ A3 } & $\begin{array}{c}\text { Pembin } \\
\text { a, IV/a }\end{array}$ & $\begin{array}{c}15 \\
0\end{array}$ & 15 & 5 & 6 & 5 & 10 \\
\hline
\end{tabular}




\begin{tabular}{|c|c|c|c|c|c|c|c|c|c|c|c|}
\hline 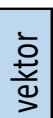 & 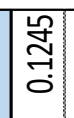 & \begin{tabular}{|c|} 
\\
0 \\
0 \\
0
\end{tabular} & 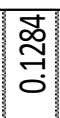 & : & 㟋 & 兽 & \begin{tabular}{|l|} 
\\
8 \\
0 \\
0
\end{tabular} & 负 & \begin{tabular}{|l|} 
\\
\\
0 \\
0 \\
0
\end{tabular} & \begin{tabular}{|l|} 
\\
\\
0 \\
0 \\
0
\end{tabular} & \\
\hline 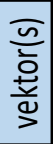 & 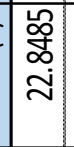 & 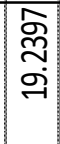 & $\begin{array}{l}\vec{r} \\
\stackrel{0}{\circ} \\
\tilde{\sim}\end{array}$ & 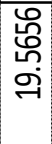 & 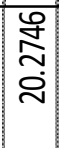 & 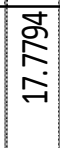 & 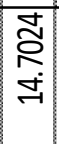 & 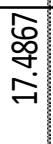 & 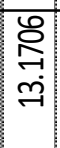 & 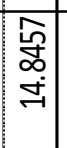 & 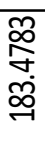 \\
\hline 8 & $\begin{array}{l}8 \\
-1\end{array}$ & $\underset{i}{\stackrel{g}{g}}$ & $\underset{f}{\stackrel{g}{i}}$ & $\underset{-}{8}$ & 岕 & 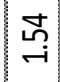 & $\underset{f}{\stackrel{g}{i}}$ & $\underset{\sim}{\stackrel{8}{-}}$ & $\stackrel{g}{\rightarrow}$ & $\underset{F}{F}$ & \\
\hline ک & 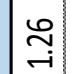 & 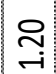 & $\underset{\sim}{\sim}$ & $\underset{\sim}{\sim}$ & $\stackrel{\sim}{\rightarrow}$ & $\stackrel{2}{\rightarrow}$ & $\underset{-1}{8}$ & $\underset{\sim}{\stackrel{\overbrace{}}{-}}$ & 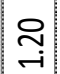 & $\stackrel{\stackrel{2}{\rightarrow}}{\rightarrow}$ & \\
\hline U & $\left|\begin{array}{c}\infty \\
\hdashline \\
-i\end{array}\right|$ & 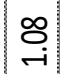 & 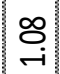 & $\underset{\sim}{\mathrm{i}}$ & 家 & $\stackrel{8}{0}$ & 녕 & $\underset{\sim}{\stackrel{\theta}{-}}$ & 亩 & 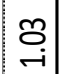 & \\
\hline$\widetilde{0}$ & 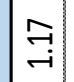 & $\underset{ }{\exists}$ & 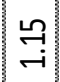 & $\stackrel{m}{\rightarrow}$ & $\stackrel{m}{\rightarrow}$ & 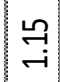 & 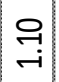 & 음 & 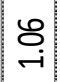 & 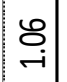 & \\
\hline$\widetilde{\mho}$ & $\left|\begin{array}{c}\infty \\
-i\end{array}\right|$ & $\mid$ & 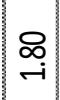 & {$\left[\begin{array}{l}0 \\
\sigma \\
\sim\end{array}\right.$} & $\stackrel{\sim}{\stackrel{2}{\sigma}}$ & $\stackrel{2}{\circ}$ & $\stackrel{n}{n}$ & $\stackrel{n}{\rightarrow}$ & $\stackrel{n}{n}$ & {$\left[\begin{array}{c}\underset{\omega}{\sigma} \\
\rightarrow\end{array}\right]$} & \\
\hline 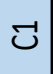 & $\left|\begin{array}{l}\mathscr{8} \\
\dot{\nabla}\end{array}\right|$ & 曽 & 点 & $\mid \begin{array}{l}\mathscr{8} \\
\dot{\gamma}\end{array}$ & 点 & I\% & $\mid \begin{array}{l}\mathscr{8} \\
\dot{8}\end{array}$ & $\stackrel{\mathscr{Q}}{+}$ & $\stackrel{\leftrightarrow}{\rightarrow}$ & $\mid \begin{array}{l}\mathscr{Q} \\
\dot{q} \\
\dot{\gamma}\end{array}$ & \\
\hline $\begin{array}{l}\text { 등 } \\
\text { o. } \\
\text { 응 } \\
0\end{array}$ & 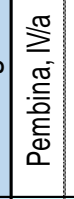 & 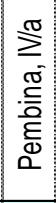 & 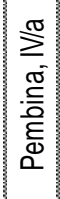 & 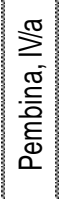 & 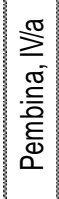 & 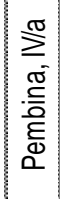 & 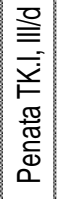 & 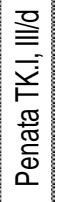 & 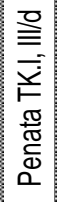 & 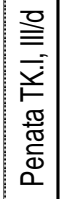 & \\
\hline 亗 & $\vec{\alpha}$ & $\stackrel{\sim}{\gtrless}$ & 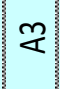 & 导 & $\stackrel{2}{<}$ & $\frac{1}{2}$ & \& & $\stackrel{\infty}{<}$ & 昰 & 울 & \\
\hline
\end{tabular}

\subsubsection{Penentuan perangkingan}

\section{metode weighted product}

Table berikut adalah perhitungan rangking untuk metode weighted product. Dalam tabel 4.5 inidapat dijelaskan bahwa rangking 1 sampai rangking 6 ada pada kelompok golongan yang sama yaitu Pembina, sedangkan rangking 7 sampai 10 ada pada kelompok golongan penata. Dapat disimpulkan bahwa kelompok golongan paling atas harus terpenuhi dulu semua untuk proses kenaikan pangkat, sedangkan kenyataannya golongan dibawahnya jika variable angka kredit bagus isa naik pangkat duluan daripada golongan diatasnya. Tabel berikut adalah hasil perangkingan metode weighted product.

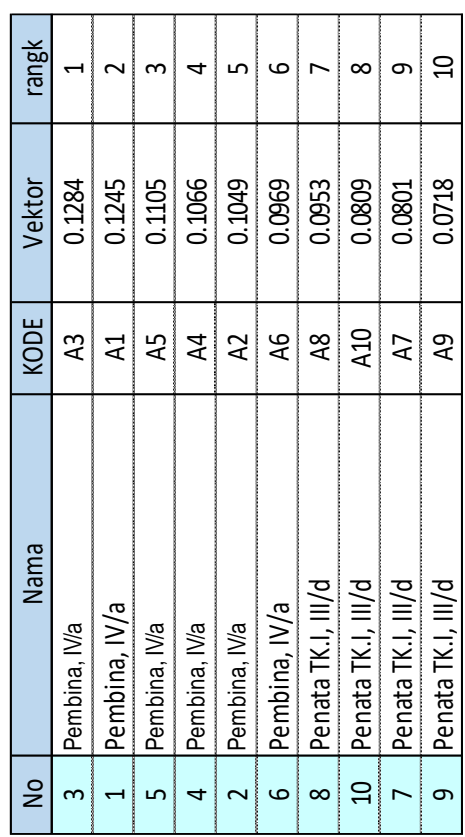

Tabel 4.5 Perangkingan metode weighted product

\subsubsection{Penentuan nilai vector}

Dengan menggunakan rumus persamaan pada metode wighted product didapatkan nilai vector seperti terlihat pada table 4.4

Tabel 4.4 Penentuan nilai vektor 


\begin{tabular}{|c|c|c|c|c|c|c|c|c|c|c|c|}
\hline$\vec{\Delta}$ & 崫 & $\begin{array}{l}\text { 웧 } \\
\text { : }\end{array}$ & 总 & : & 兽 & 兽 & 官 & 悤 & $\stackrel{\infty}{\circ}$ & 兽 & \\
\hline & 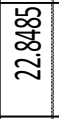 & $\begin{array}{l}\text { 总 } \\
\text { ğ }\end{array}$ & \begin{tabular}{l|} 
宽 \\
ळ \\
$\sim$
\end{tabular} & 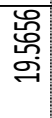 & 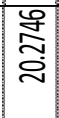 & $\begin{array}{l}\text { 总 } \\
\stackrel{\text { I }}{*}\end{array}$ & \begin{tabular}{l} 
范 \\
\multirow{a}{*}{}
\end{tabular} & 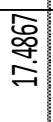 & 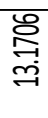 & $\begin{array}{l}\text { 厗 } \\
\text { ज्ञ }\end{array}$ & 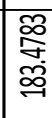 \\
\hline & $\underset{\sim}{\stackrel{\leftrightarrow}{-}}$ & $\stackrel{\text { 孚 }}{ }$ & 总 & $\underset{\sim}{\stackrel{8}{*}}$ & 营 & 壱 & $\underset{ }{\stackrel{9}{-}}$ & : & 导 & 寻 & \\
\hline 3 & $\mid$ & $\underset{్}{\overparen{్}}$ & $\underset{ت}{\sim}$ & 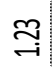 & $\stackrel{\text { 号 }}{=}$ & 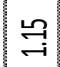 & $\underset{\mathrm{i}}{\mathrm{i}}$ & $\underset{్}{\overparen{్}}$ & 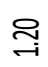 & 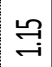 & \\
\hline J & 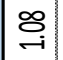 & 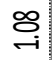 & $\underset{\sim}{\infty}$ & $\underset{\sim}{\stackrel{-}{-}}$ & $\underset{\sim}{\stackrel{-}{i}}$ & $\stackrel{9}{9}$ & $\stackrel{\text { L }}{-}$ & $\underset{\sim}{\stackrel{\leftrightarrow}{-}}$ & $\stackrel{्}{\circ}$ & ס्G & \\
\hline$m$ & 学 & 学 & $\stackrel{\text { 孛 }}{\rightarrow}$ & $\stackrel{\dddot{I}}{\rightarrow}$ & $\stackrel{\dddot{I}}{\rightarrow}$ & 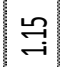 & 윽 & 윽 & $\stackrel{\leftrightarrow}{\circ}$ & $\stackrel{8}{\circ}$ & \\
\hline$\checkmark$ & $\mid \begin{array}{c}\underset{\sim}{\sim} \\
\mid\end{array}$ & $\underset{\rightarrow}{\stackrel{乛}{\sigma}}$ & $\underset{\rightarrow}{\stackrel{9}{\rightarrow}}$ & $\stackrel{20}{-i}$ & 岕 & $\stackrel{s}{-\infty}$ & $\stackrel{\coprod}{\rightarrow}$ & $\stackrel{\overbrace{}}{\rightarrow}$ & $\stackrel{\overbrace{}}{\sim}$ & $\stackrel{\text { 岁 }}{\rightarrow}$ & 要 \\
\hline ت & $\mid \begin{array}{l}\mid \% \\
\end{array}$ & 曽 & 홍 & 离 & 空 & 89 & $\underset{8}{\mathscr{8}}$ & $\stackrel{8}{8}$ & $\stackrel{\stackrel{2}{\sigma}}{\square}$ & 曽 & \\
\hline $\begin{array}{l}\text { 동 } \\
\text { : } \\
\text { 잉 }\end{array}$ & 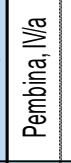 & 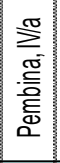 & 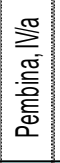 & 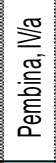 & 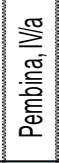 & 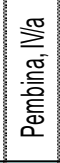 & 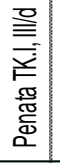 & 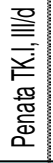 & 总 & 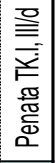 & \\
\hline 岩 & $\vec{z}$ & $\approx$ & $\dddot{\chi}$ & 安 & 足 & 里 & $\approx$ & $\stackrel{\infty}{\alpha}$ & 운 & 울 & \\
\hline
\end{tabular}

\subsubsection{Penentuan perangkingan} metode weighted product

Table berikut adalah perhitungan rangking untuk metode weighted product. Dalam tabel 4.5 inidapat dijelaskan bahwa rangking 1 sampai rangking 6 ada pada kelompok golongan yang sama yaitu Pembina, sedangkan rangking 7 sampai 10 ada pada kelompok golongan penata. Dapat disimpulkan bahwa kelompok golongan paling atas harus terpenuhi dulu semua untuk proses kenaikan pangkat, sedangkan kenyataannya golongan dibawahnya jika variable angka kredit bagus isa naik pangkat duluan daripada golongan diatasnya. Tabel berikut adalah hasil perangkingan metode weighted product.

Tabel 4.5 Perangkingan metode weighted product

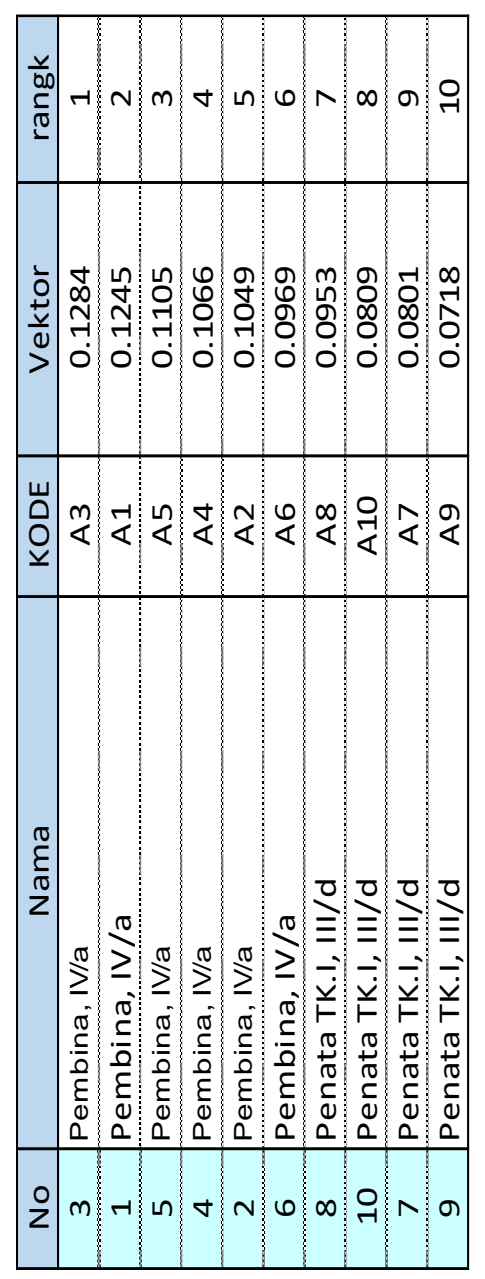

\subsection{Simulasi Metode Promethee}

\subsubsection{Evaluasi kandidat pegawai}

Data kandidat yang dipilih untuk mengikuti pemilihan promosi jabatan dapat ditunjukkan pada tabel berikut. Terdapat 10 sample yang diujicobakan pada evaulasi kandidat yang terpilih seperti pada tabel 4.6 
Tabel 4.6 Evaulasi kandidat pegawai metode promethee

\begin{tabular}{|c|c|c|c|c|c|c|c|c|c|c|c|}
\hline 8 & 의 & 잉 & 이 & $\stackrel{2}{2}$ & $\approx$ & & & & & & $\infty$ \\
\hline ك & $0 \mid$ & 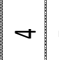 & n & in & $\mathrm{m}$ & $m$ & & + & & 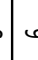 & $\sim$ \\
\hline 士 & 0 & 0 & - & n & in . & & & 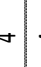 & & 4 & $\sim$ \\
\hline ช & 0 & 0 & in & $\nabla$ & + & & & $m$. & & 4 & $\sim$ \\
\hline 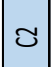 & 느 & $\approx$ & $\stackrel{2}{2}$ & 이 & 의 & $\Rightarrow$ & $\infty$ & $\infty$ & & 4 & $\infty$ \\
\hline$\Xi$ & 우 & 8 & ?口: & 으. & @્વ & 의 & & 인 & & 5 & 8 \\
\hline $\begin{array}{l}\text { 댕 } \\
\text { o. } \\
\text { 응 }\end{array}$ & 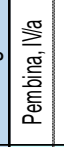 & 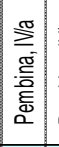 & 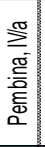 & 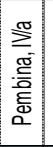 & 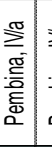 & 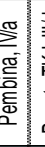 & 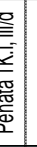 & 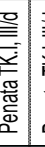 & & & 言 \\
\hline & $\vec{\alpha}$ & $\approx$ & ₹ & \& & 足 & & & & & & \\
\hline
\end{tabular}

\subsubsection{Normalisasi matrik}

Tabel dibawah adalah perhitungan normalisasi matrik.

Tabel 4.7 Normalisasi matrik

\begin{tabular}{|c|c|c|c|c|c|c|c|c|c|c|}
\hline & 8 & gृ & \% & 8 & 5 & 窎 & 8 & 웅 & 8 & \\
\hline & 웅 & 5 & $\stackrel{1}{\circ}$ & & $\ddot{g}$ & & 8 & 용 & 8 & દ̆ \\
\hline & & & & & $\ddot{g}$ & 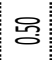 & $\stackrel{2}{6}$ & 용 & 용 & $\xi$ \\
\hline & 응 & $£$ & 2 & & 8 & $\ddot{3}$ & 2 & $\stackrel{2}{2}$ & 8 & \\
\hline & & & & & 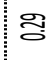 & & 8 & 8 & 8 & \\
\hline & 영 & F & 8 & F & 8 & F & 羊 & 春 & 8 & 3 \\
\hline & 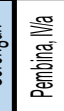 & & 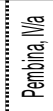 & 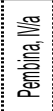 & 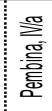 & 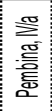 & 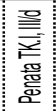 & 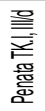 & 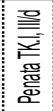 & 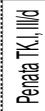 \\
\hline & $\vec{x}$ & $z$ & $\dddot{q}$ & $\neq$ & 눙 & $\div$ & $\approx$ & $\infty$ & 운 & \\
\hline
\end{tabular}

\subsubsection{Perangkingan Metode}

\section{Promethee}

Berikut adalah hasil perhitungan rangking metode promethee. Terlihat perhitungan rangking dilakukan secara acak tentunya sesuai nilai angka net flow tertinggi dan ini adalah yang paling akurat Karena perangkingan tidak dilakukan berdasarkan kelompok golongan yang sama.

Tabel 4.10 Perangkingan promethee

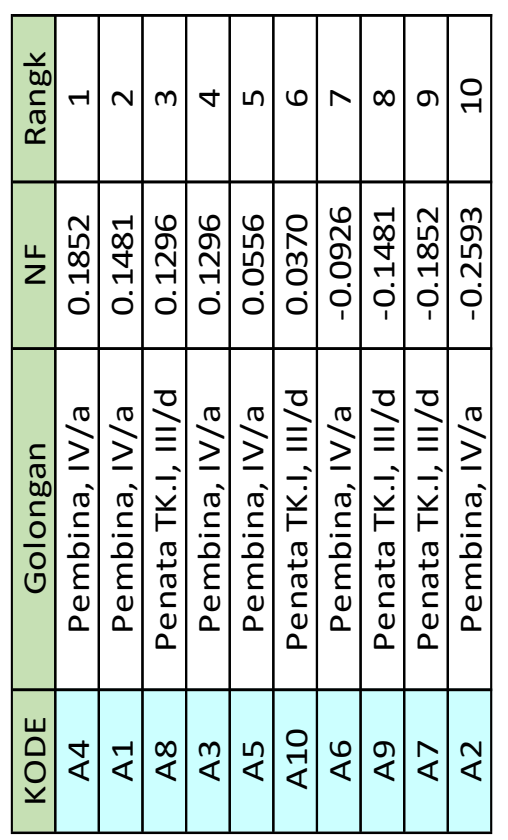

\section{SIMPULAN DAN SARAN}

\subsection{Simpulan}

Dari pengukuran kinerja dengan melakukan komparasi dua algoritma yang telah dilakukanberdasarkan jumlah data maka dapat disimpulkan bahwa algoritma Promethee memiliki 
kemampuan dalam pengambilan keputusan untuk menentukan keputusan kenaikan pangkat jabatan fungsional Pol PPyang lebih baik. Kedua algoritma Weigted Product dan Promethee dapat digunakan dalam menentukan perangkingan berdasarkan evaluasi variable-variabel kriteria yang diuji debgan menggunakan nilai angka kredit yang didapat setiap kandidat. Kedua algoritma ini dikomparasi kemudian diuji akurasinya. Tingkat akurasi tertinggi lah yang digunakan dalam menentukan system pendukung keputusan jabatan fungsional pegawai. Maka hasil penelitian dari percobaan yang telah dilakukan dapat disimpulkan bahwa:

1. Algoritma promethee memiliki tingkat akurasi tertinggi yaitu $86.37 \%$ sedangkan weighted product sebesar $80.89 \%$ maka selisih diantaranya sebesar 6\%. Model algoritma Prometheedapat melakukan perangkingan secara acak tanpa melihat kelompok golongan, yang artinya jika ada 100 data maka metode promethe akan melakukan system perhitunga rangking sesuai dengan angka kredit tertinggi tanpa melihat terlebih dahulu kelompok golongan yang ada.

2. Rule yg dihasilkan algoritma prometheemelalui bererapa tahap lebih banyak daripada rule weighted product. Berdasarkan akurasi yg dihasilkan prototype menunjukkan bahwa metode dan prototype yg diterapkan sudah baik dalam memprediksi keputusan kenaikan jabatan fungsional berdasarkan angka kredit.

Dari hasil penelitian ini diharapkanalgoritma terpilih yaitu algoritma promethee dalam memprediksi keputusan kenaikan pangkat jaatan fungsional berdasarkan nilai angka kredit lebih tepat dan cepat, sehingga membantu system penunjang keputusan yang lebih baik.

\subsection{Saran}

Agar penelitian ini bisa ditingkatkan, berikut adalah saran-saran yang diusulkan:

1. Penelitian ini dapat dikembangkan dengan metode optimasi lainnya seperti Ant Colony Optimization (ACO), Genetic Algorithm (GA), fuzzy, topsis dan lainnya.

2. Penelitian ini dapat dikembangkan dengan metode klasifikasi data mining lainnya seperti Naive Bayes, C.6, KNN dan lainnya untuk melakukan perbandingan. 


\section{DAFTAR PUSTAKA}

1. Agus Perdana Windarto, 2017, Implementasi metode topsis dan saw dalam memberikan reward pelanggan,” Kumpul. J. Ilmu Komput., vol. 04, no. 01, pp. 88-101.

2. Berndtssom 2008 Berndtssom, M., Hansson, J., Olsson, B., \& Lundell, B. A Guide For

Students In Computer Science

And Information Systems.

London: Springer, 2008.

3. Dawson 2009 Dawson, C. W. Projects In Computing And Information System A Student's Guide. England: AddisonWesley, 2009.

4. Hillier, S.F., dan Lieberman, J.G., 2008, Introduction to Operations Research-eight edition (diterjemahkan oleh Dewa, K. P., Ai, J. T., Wigati, S.S. dan Hardjono, D.), Andi, Yogyakarta.

5. Jasril, Haerani, E., Afrianty, I., 2011, Sistem Pendukung Keputusan (SPK) Pemilihan Karyawan Terbaik Menggunakan Metode Fuzzy AHP (F-AHP), Prosiding Seminar Nasional Aplikasi Teknologi Informasi 2011 (SNATI 2011), Yogyakarta.

6. Jaya Putra.2013. Sistem Pendukung Keputusan Penentuan Bonus Karyawan Menggunakan Metode Weighted Product ( Studi Kasus : PT. Gunung Sari Medan ). Pelita Informatika Budi Darma, Volume : V, Nomor : 2, Desember 2013.
7. Keen, P. G. W. (1980). Adaptive Design for Decision Support Systems, Data Base, Vol. 12, No. 1 dan 2.

8. Konsumen Dalam Keputusan Pembelian (Studi Produk Perawatan Bayi Johnsons Baby). Tes., Universitas Indonesia, 2010

9. Kotler 2009, 245 Batubara, Muhamad Hendri. Strategi Marketing Public Relation (MPR) Berupa Promosi Dan Sponsorsip Untuk Mempengaruhi

10. Kusumadewi, S., et.all. (2006). "Fuzzy Multi-Attribute Decision Making (FUZZY MADM)", Graha Ilmu, Yogyakarta.

11. Larose, D. T. (2005). Discovering Knowledge in Data. New Jersey: John Willey \& Sons, Inc. ISBN 0-47166657-2.

12. L. Shi, B. Sun, L. Kong, and Y. Zhang. (2009). "Web Forum Sentiment Analysis based on Topics, " pp. 148-153

13. Little, J. D. C. (1970). Models and Managers: The Concept of a Decision Calculus, Management Science, Vol. 16, N0. 8.

14. Magdalena, H., 2012, Sistem Pendukung Keputusan untuk Menentukan Mahasiswa Lulusan terbaik di Perguruan Tinggi (Studi Kasus STMIK Atma Luhur Pangkalpinang, Prosiding Seminar Nasional teknologi Infromasi dan Komunikasi 2012 (SENTIKA 2012), Yogyakarta.

15. Rani,Sasika. (2014). "Sistem Pendukung Keputusan Pemilihan Sepeda Motor Berbasis Web Dengan MetodeWeighted Product". Skripsi. Teknik informatika, STMIK Budidarma Medan. 
16. R. Hanifah. 2015. Implementasi Metode Promethee Dalam Penentuan Penerima Kredit Usaha Rakyat (KUR)," J. Teknol., vol. 8, no. 2, pp. 169177.

17. S. Pami. 2013. Sistem Pendukung Keputusan Pemilihan Karyawan Terbaik Dengan Metode Promethee (Studi Kasus: PT. Karya Abadi Mandiri), Vol. V, No. July, Pp. 21-26.

18. T. Imandasari and A. P. Windarto, 2017, Sistem Pendukung Keputusan dalam Merekomendasikan Unit Terbaik di PDAM Tirta Lihou Menggunakan Metode Promethee,J. Teknol. dan Sist. Komput., vol. 5, no. 4, p. 159.

19. Turban, E., Aronson, E.J. and Liang, T.P., 2005, Decision Support System and Inteligent System (diterjemahkan oleh Prabantini, D.), edisi 7 jilid 1, Andi, Yogyakarta.

20. Turban, Efraim, et al.(2005).Decision Support Systems and Intelligent Systems.7th Ed. New Jersey. Pearson Education. 